\title{
Groundwater Data Collection and Analysis in Baharia Oasis
}

\author{
Mohamed El-Barad, Heba Ahmed Mosalam, Ahmed A.Hassan, Peter Riad
}

\begin{abstract}
Groundwater is considered as one of the main resources especially in remote area. The ground water samples are taken from different areas in the study area (Baharia Oasis). Groundwater samples have been analyzed in specialized water quality lab. It was noticed that the iron concentration percentage is higher than the standard limit in most of areas. Using Geographic Information System, the percentage of iron concentration in different unknown areas could be predicted. The results showed that $\mathrm{min}$ iron concentration is $0.07 \mathrm{mg} / \mathrm{l}$ and the max is $10.5 \mathrm{mg} / \mathrm{l}$. It is recommended to apply an oxidation process in different wells and predict the others using the same process to provide people with safe and sustain drinking water.
\end{abstract}

Keywords: Groundwater, GIS, Data Analysis, Baharia Oasis, Groundwater Sample.

\section{INTRODUCTION}

The research is working in the western desert in Baharia Oasis. Water sample is faced highly concentration of iron in the area surrounding Baharia. In order to know the concentration of iron in an area such as Baharia oases, this required a specific technique. It is impossible to take water samples at every point, but samples can be taken in separate areas and use an interpolation methods and mathematical equations to predict each point. Geographic Information System (GIS) is a suitable tool for predict the unknown value depending on other different values.

Baharia is located in It is in the middle of the Western Desert of Egypt, has a length of $94 \mathrm{~km}$, a maximum width of $42 \mathrm{~km}$, located between $27^{\circ} 42^{\prime}$ and $28^{\circ} 35^{\prime} \quad \mathrm{N}$ and between $28^{\circ} 30^{\prime}$ and $29^{\circ} 10^{\prime} \quad \mathrm{E}$ and connected with Cairo city by Cairo Wahat Desert road, but it is administratively affiliated

Revised Manuscript Received on August 15, 2020.

* Correspondence Author

Mohamed El-Barad *, Construction Dept., Faculty of Engineering, Egyptian Russian University, Badr City, Cairo, Egypt, 11829. Email: Mohamed.fahmy@eru.edu.eg

Heba Ahmed Mosalam, 3Energy Dept., Faculty of Engineering, Heliopolis University for Sustainable Development, Belbeis Desert Road, Cairo, Egypt, 11785. Email: heba.mosalam@hu.edu.eg

Ahmed A.Hassan, Irrigation and Hydraulics Dept., Faculty of Engineering, Ain Shams University, Cairo, Egypt Email: ahmed9657@yahoo.co.uk

Peter Riad, Irrigation and Hydraulics Dept., Faculty of Engineering, Ain Shams University, Cairo, Egypt Email: ph4318@yahoo.com

(C) The Authors. Published by Blue Eyes Intelligence Engineering and Sciences Publication (BEIESP). This is an open access article under the CC BY-NC-ND license (http://creativecommons.org/licenses/by-nc-nd/4.0/) with Giza governorate. $375 \mathrm{~km}$ from Giza Governorate in the south-west direction. It is located on a depression with an area covered 2700-kilometer meters' square. Baharia is an important center of agriculture and tourism, The following map will illustrate Baharia oasis location (ELNAGGAR A.A., 2014). Fig. 1 shows the location of Baharia oasis in Egypt and main boundaries of Baharia. Baharia Oasis consist of many small shallow depressions Mandisha 119 m and Bawiti \& el qaser $113 \mathrm{~m}$ in north. El-Rayes in south east and Elgiz in south west $156 \mathrm{~m}$ (Essawy, 1989).

The figure, graph, chart can be written as per given below schedule.

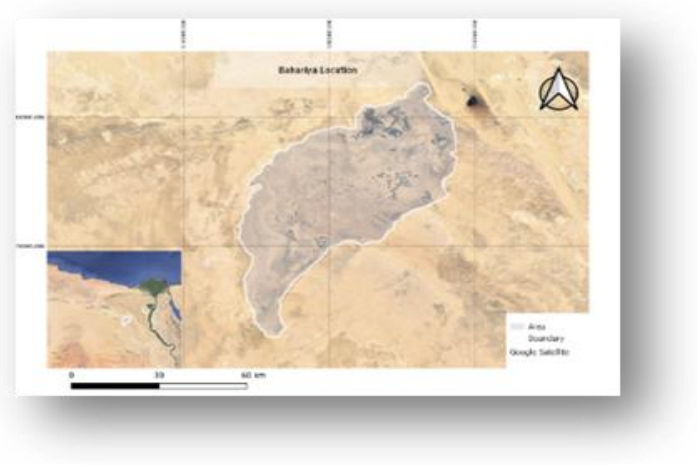

Fig. 1: Baharia Location

Economic iron ore deposits with an average of 47.6 wt.\% of Fe occur in the Baharia Oasis. The ores are situated at the northern part of the depression and extend over an area of $11.7 \mathrm{~km} 2$ with a thickness varying from 2 to $35 \mathrm{~m}$, averaging 9 $\mathrm{m}^{1}$. The major problem for underground water in El-Wahat el-Baharia is iron concentration. The standard concentration limits is $0.3 \mathrm{mg} / \mathrm{l}$ according to who. Iron contamination can present a number of problems for water filtration systems for agricultural, industrial and municipal applications. Daniel Ityel of Amiad Filtration Systems outlines the problems and introduces a new method of micro-fibre filtration after oxidation ${ }^{2}$. Geographic Information System analysis used in many application like site selection, pollution monitoring, water analysis and waste water ${ }^{3}$. It can not only represent the data geographically, but also it can support decision making using different tools ${ }^{4}$. Geographic Information System was used in Karnataka, India for mapping ground water samples. Taking 178 bore wells of Karnataka state of India. The process took about one year. Sampling and measurements were carried out from 2013 to 2014. The data obtained can provide information for to make decisions about potential future drinking water regulations ${ }^{5}$.

\section{Published By:}

Blue Eyes Intelligence Engineering DOI: 10.35940/ijeat.F1642.089620

and Sciences Publication

(C) Copyright: All rights reserved.

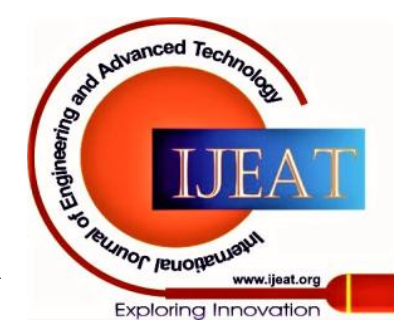




\section{Groundwater Data Collection and Analysis in Baharia Oasis}

Application of GIS and Remote Sensing integrated has been used to explore the groundwater in Al-Wala Basin in Jordan ${ }^{6}$. Different GIS functions of intersection and spatial query were then applied to produce the final map for the most promising sites for groundwater exploration.

Results showed that spatial distribution of the most promising sites for groundwater exploration was dependent on the interrelated factors of lithology, topography and geologic structure. The most promising sites were distributed within $4 \%$ of the study area. The highest percentage of groundwater wells was within the alluvial and wadi sediments. The study showed that remote sensing and GIS provided efficient tools for mapping of groundwater exploration. One of the main challenges in any research is data availability. The research combined between two different methodologies of data acquired. The first one is historical data from previous researches and thesis and the second is working on the ground and talking ground water sample which required hard effort and permits to take these samples. The Main objective of this research is to create an obvious picture of the situation that the groundwater suffers from, especially the iron concentration in the groundwater. Using a Geographic Information system can predict the percentage of iron concentration in different unknown area depending on data collecting from the field and other data.

\section{MATERIALS AND METHODS}

For study and monitoring certain area, especially in water quality, it needs samples of data to measure iron concentration to determine soluble iron in water. Soluble iron can be detected by pumping amount of air pressure in a clear glass full of water; reddish brown particles will appear in the glass and eventually settle to the bottom. It is necessary to take a random sampling of a number of water sources and establishing which sources have either iron or bacteriological contamination, or both, then determine the water quality standards that will be needed to achieve.

It is important to mention that there are data acquired from different sources and other field work done during the study. Both data collected and filtered for preparing to the next step which is the analysis phase. Fig. 2 shows the bottles of water collecting from different wells in Baharia.

Remote sensing and Geographic Information System are used for visualization the data as a first step in analysis phase. The second step is to filter the data collected from wells after that visualizing the data using Geographic Information System. The last step is to analyze the data selected and predict the iron concentration in other unknown area

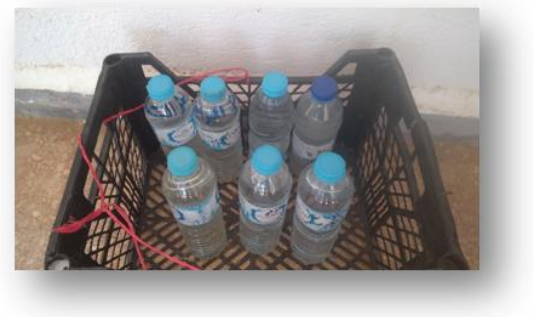

Fig. 2 : Water Sample

\section{RESULTS AND DISCUSSION}

Thirty three water samples have been taken from different wells with different locations. All water sample tested and listed in the Table (1).

Table 1: water sample before filtration

\begin{tabular}{|c|c|c|c|c|c|}
\hline Sample & $\mathbf{F e}$ & Sample & $\mathbf{F e}$ & Sample & $\mathbf{F e}$ \\
\hline 1 & 4.2 & 12 & 26 & 23 & 3.4 \\
\hline 2 & 5.2 & 13 & 1.8 & 24 & 3.3 \\
\hline 3 & 0.3 & 14 & 0.8 & 25 & 1.1 \\
\hline 4 & 0.2 & 15 & 0.9 & 26 & 6.1 \\
\hline 5 & 0.2 & 16 & 1.6 & 27 & 6.6 \\
\hline 6 & 0.2 & 17 & 0.8 & 28 & 6.8 \\
\hline 7 & 26 & 18 & 4.1 & 29 & 4.4 \\
\hline 8 & 0.07 & 19 & 1.3 & 30 & 5.8 \\
\hline 9 & 41 & 20 & 2.8 & 31 & 8.2 \\
\hline 10 & 0.3 & 21 & 0.6 & 32 & 9.5 \\
\hline 11 & 1.8 & 22 & 2.8 & 33 & 10 \\
\hline
\end{tabular}

Iron concentration for each well can be represented using graphical chart. Data filtration have to implement after listed in graphically representation shows in Fig. 3. It is noticed that the well number seven, nine and twelve has a greater value than the other values. The three different value omitted and not including in the further steps of analysis

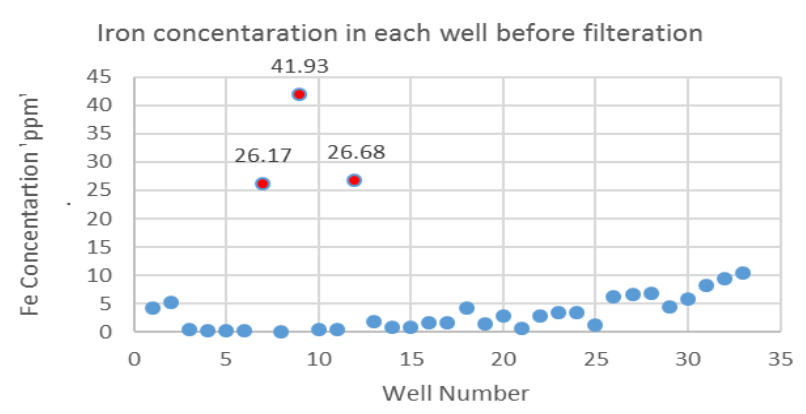

Fig. 3 : Iron concentration in each well before omitted the three wells

Fig. 4. shows the data representation after omitted the three extreme values from water sample. Statistical data analysis provide the following information; the mean value of the iron concentration in Bahrayia oasis is 3.2 'ppm'. The median value is 2.34 'ppm'. The minimum and maximum of the value is 0.07 and 10.5 'ppm'. Rang of our data is 10.43 'ppm'. Standard deviation of the water sample is 2.96 'ppm' and variance is 8.79 'ppm'

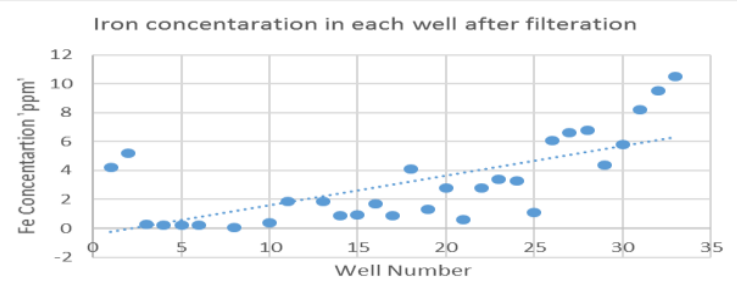

Fig. 4: Iron concentration in each well after omitted the three wells

Published By:

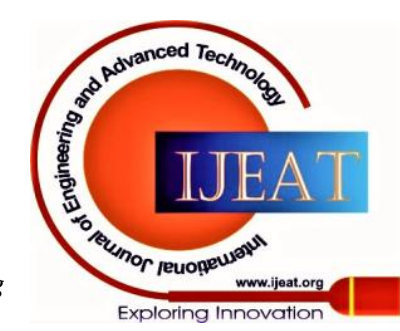




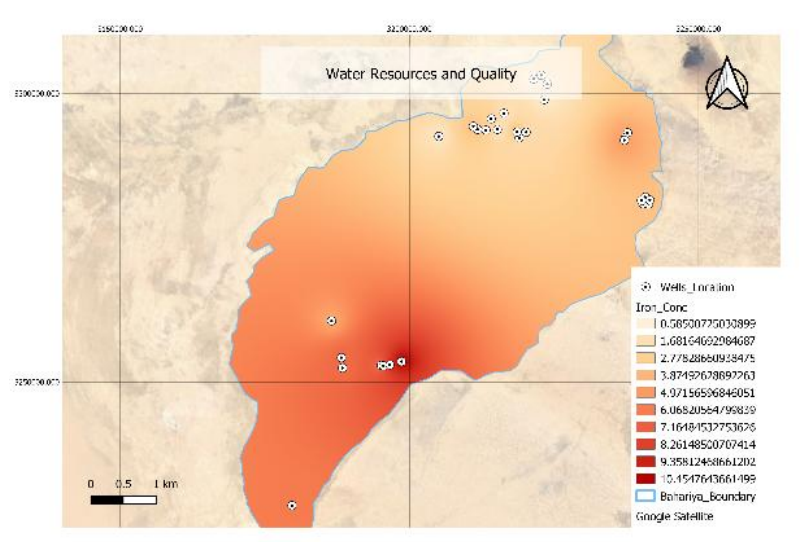

Fig. 5 : Wells Location and Iron Concentration

Geographic information System can link between the location of the well and sample water analysis. It can visualize and analyze the water quality in Baharia Oasis. Geographic information system using an interpolation methods for creation a thematic map for iron concentration in Baharia Oasis. Fig. 5 shows the result of interpolation method. White circle shows the location of each well and the dark color shows the more iron concentration.

\section{CONCLUSION AND RECOMMENDATION}

Research predicted that in Baharia Oasis, The southern area is highly iron concentration than the northern area. Iron concentrations in groundwater range from 0.07 to 10.5 ' $\mathrm{ppm}$ ' in Baharia Oasis. It is proposed that the suitable location for drilling new well is the western north or eastern north.

The research recommended to apply oxidation process in different wells in Baharia Oassis, also to take another samples before and after treatment process. Artificial neural network can be used for predict the suitable treatment methods and result.

\section{REFERENCES}

1. M.Baioumy H, Z.Khedr M, Ahmed AH. Mineralogy, geochemistry and origin of $\mathrm{Mn}$ in the high-Mn iron ores,Baharia Oasis, Egypt.pdf. Ore Geol Rev. 2013;53:63-76.

2. Ityel D. Ground water: Dealing with iron contamination. Filtr Sep. 2011;48(1):26-28. doi:10.1016/S0015-1882(11)70043-X

3. Javaheri H, Nasrabadi T, Jafarian MH. Site Selection of Municipal Solid Waste Landfills Using Analytical Hierarchy Process Method in a Geographical Information Technology Environment in Giroft. J Environ Heal Sci Eng. 2006;3(3):177-184.

4. Sayed E, Riad P. Multi criteria analysis for groundwater management using solar energy in Moghra Oasis, Egypt. In: Egyptian Journal of Remote Sensing and Space Science. National Authority for Remote Sensing and Space Sciences; 2019. doi:10.1016/j.ejrs.2019.04.001

5. Sarvajayakesavalu S, Lakshminarayanan D, George J. Geographic Information System mapping of gross alpha/beta activity concentrations in ground water samples from Karnataka, India: A preliminary study. Groundw Sustain Dev. 2018;6:164-168. doi:10.1016/J.GSD.2017.12.003

6. Al-Bakri JT, Al-Jahmany YY. Application of GIS and Remote Sensing to Groundwater Exploration in Al-Wala Basin in Jordan. J Water Resour Prot. 2013.

\section{AUTHORS PROFILE}

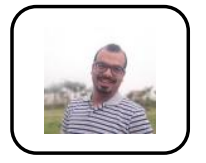

Mohamed El-Barad Mohamed Ahmed Mohamed Fahmy El-Barad is a $\mathrm{PhD}$ researcher at Ain Shams University in Cairo, Egypt. He hold a Master Degree from Faculty of Engineering Ain shams university. He studied a Master of Business Administration at Cardiff
Metropolitan University - United Kingdom. He is working as a Teaching assistant at Egyptian Russian University at Bade City. He attendant many conference in Egypt and outside.

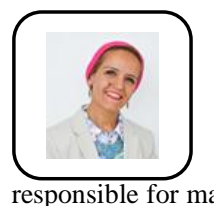

Heba Ahmed Mosalam Heba Mosalam is Lecturer of Renewable Energy in Energy Program at Heliopolis University in Cairo, Egypt since 2014. Before coming to Heliopolis University was the deputy of the maintenance manager for Germany Diesel Engine where she was responsible for maintaining the quality of the engine as heavy duty of over 100 staff engaged in services and developed in 22 countries around the world. Heba studied Mechanical Engineering, Production for her bachelor's degree and Environmental Engineering at Ain Shams University for her $\mathrm{PhD}$. She is Author for more than 15 conference papers related to environmental awareness and Environmental Impact Assessment

Mosalam is a member of the environmental council for ministry of Culture. And supervised two post graduate students to fulfill master and $\mathrm{PhD}$ requirement.

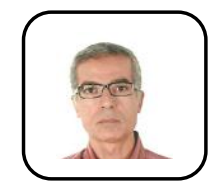

Ahmed A. Hassan Ahmed Aly Hassan studied Civi Engineering at Ain Shams University from 1975 to 1980. He was awarded his Master of Science in Ain Shams University. He conducted his Ph.D. research work in Technical University Braunschweig in Germany from 1986 to 1988 and his promotion was in Ain Shams University in 1989. The topic of his Ph.D. research work was "Groundwater Quantity and Quality Modeling". He developed a 2-D finite element model for simulating groundwater flow and contaminant transport in porous media. Hassan worked as a demonstrator from 1980 to 1984 , assistant lecturer from 1984 to 1988, lecturer from 1989 to 1995 and assistant professor from 1995 to 2001 in the Irrigation and Hydraulics Department of the Faculty of Engineering, Ain Shams University. Hassan has been working as Professor of Environmental Hydrology in Ain Shams University since 2001. The published research articles are more than 60 in the fields of Irrigation, Hydraulics and Hydrology and supervised many of the M.Sc. and Ph.D. candidates in all Egyptian Universities. Prof. Hassan works as a consultant in the fields of Water Engineering and Hydrology.

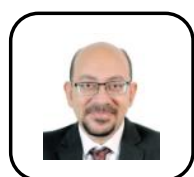

Peter Riad Dr. Peter Riad is Associate Professor at Irrigation and Hydraulics Department, Faculty of Engineering-Ain Shams University in Cairo-Egypt. He got his MSc. from IHE-Delft/Holland in 2008 and finished his PhD at University of Hannover, Germany in 2012. He has many publications in water structures, groundwater hydrology, water management using GIS and Remote Sensing. He is a member in German-Egyptian Water Cluster and many other water organizations.
Published By:

Blue Eyes Intelligence Engineering and Sciences Publication

(C) Copyright: All rights reserved.

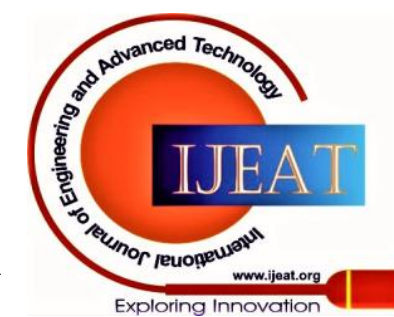

